\title{
Quality of life of people living with the human immunodeficiency virus and acquired immunodeficiency syndrome
}

\author{
Qualidade de vida de pessoas vivendo com o vírus e síndrome da imunodeficiência humana
}

Sergio Vital da Silva Júnior ${ }^{1}$, Wilton José de Carvalho Silva ${ }^{1}$, Natália Silva Lourenço ${ }^{1}$, Jordana Almeida Nogueira ${ }^{1}$, Ana Cristina de Oliveira e Silva ${ }^{1}$, Maria Eliane Moreira Freire ${ }^{1}$

Objective: to characterize the Brazilian scientific production on the quality of life of people living with human immunodeficiency virus/Acquired Immunodeficiency Syndrome. Methods: bibliometric study with 20 dissertations and 18 theses available at the Brazilian Digital Library of Theses and Dissertations. The empirical material was submitted to descriptive and inferential statistics using the R-Project software version 3.5.1a. Results: studies on the theme increased from 2006 to 2012. The majority came from the Northeast and Southeast regions and was mainly conducted in the Nursing and Psychology areas. The use of specific instruments to evaluate the quality of life of people living with human immunodeficiency virus or acquired immunodeficiency syndrome was evident. Conclusion: there is a significant Brazilian scientific production on the theme, with evidence regarding the physical, social and psychoemotional dimensions of the quality of life of people living with human immunodeficiency virus/Acquired Immunodeficiency Syndrome to the detriment of the cultural and spiritual/religious dimension.

Descriptors: Acquired Immunodeficiency Syndrome; HIV; Quality of Life; Nursing; Bibliometrics.

Objetivo: caracterizar a produção científica brasileira sobre qualidade de vida de pessoas vivendo com vírus da imunodeficiência humana/Síndrome da Imunodeficiência Adquirida. Métodos: estudo bibliométrico, com 20 dissertações e 18 teses, disponíveis na Biblioteca Digital Brasileira de Teses e Dissertações. 0 material empírico foi submetido à estatística descritiva e inferencial, utilizando-se o software R-Project, versão 3.5.1a. Resultados: observou-se incremento de estudos sobre a temática, no período de 2006 a 2012; a maioria oriundo das Regiões Nordeste e Sudeste do Brasil; realizados, principalmente, pelas áreas de Enfermagem e Psicologia. Evidenciouse utilização de instrumentos específicos de avaliação da qualidade de vida de pessoas que vivem com vírus ou síndrome da imunodeficiência adquirida. Conclusão: existe significativa produção científica brasileira sobre a temática, com evidências quanto à avaliação das dimensões física, social, psicoemocional da qualidade de vida de pessoas vivendo com vírus da imunodeficiência humana/Síndrome da Imunodeficiência Adquirida, em detrimento da dimensão cultural e espiritual/religiosa.

Descritores: Síndrome de Imunodeficiência Adquirida; HIV; Qualidade de Vida; Enfermagem; Bibliometria.

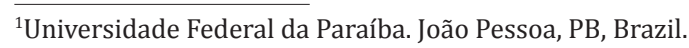




\section{Introduction}

Human Immunodeficiency Virus (HIV) infection and its manifestation through the Acquired Immunodeficiency Syndrome (AIDS) arose in the 1980s, bringing to the world population numerous clinical and social concerns. According to data from the Brazilian Ministry of Health, in 2017, 42,420 new cases of HIV infection and 37,791 of AIDS were reported in Brazil. In recent years, the rate of detection of the syndrome has decreased ${ }^{(1)}$. These numbers may be a reflection of advances in the prevention and, especially, in the treatment of the disease brought about with the introduction of efficient therapies.

With the evolution in the effectiveness of antiretroviral therapy, HIV infection has become a manageable chronic condition in which people with timely diagnosis and adequate treatment are able to have their life expectancy considerably prolonged ${ }^{(2)}$.

However, the increase in the years of life of people living with HIV and AIDS has brought undesirable aspects related to the side effects of antiretroviral therapy and the issues of stigma and prejudice that cannot be neglected since they negatively affect the quality of life of this population ${ }^{(3-4)}$.

Quality of life involves several human dimensions, including physical, psychological, social and spiritual aspects, which can have important repercussions on the reality of each individual. They may be affected by interference from the bipolarity that results from the positive and negative influences that permeate the everyday life of people, but also from the subjectivity of thoughts, feelings and emotions typical of the human being ${ }^{(5)}$.

The perception of quality of life of each person is subject to the diverse interpretations and influences of the reality in which he/she is inserted, undergoing changes throughout the life ${ }^{(6)}$. Quality of life scores of people living with HIV and AIDS are lower when compared to people without the disease or people affected by other chronic conditions ${ }^{(7)}$.

The term 'health-related quality of life' arises in the field of health sciences in this context. This term generally involves the perception of health and of the impact of physical, social, psychological and spiritual aspects on health, including health aspects in an expanded perspective ${ }^{(8)}$. This concept is broad and encompasses a variety of conditions that can influence the way the individuals perceive their daily functioning, sometimes affecting feelings and behaviors, but not limited to the physical health condition ${ }^{(9)}$.

Since the beginning of the epidemic, researchers around the world have outlined studies to assess the impact of the problem on the quality of life of people living with HIV and AIDS in order to improve the provision of health care for this population. This fact justifies the present review, because its goal is to enable health professionals to plan and implement care for these people, based on scientific evidence, regarding the dimensions of quality of life affected by HIV infection and by the treatment.

In order to know the state of the art about the subject in evidence, the present study aimed to characterize the Brazilian scientific production on the quality of life of people living with Human Immunodeficiency Virus and AIDS.

\section{Methods}

Bibliometric study using quantitative techniques capable of showing indicators that represent the state of the art of knowledge produced on a given topic. Bibliometrics has been considered an important tool for studies aimed at the characterization of scientific production, allowing greater visibility to metric studies of recorded information, such as products resulting from scientific activity, articles and scientific productions in general ${ }^{(10-11)}$. The development of the study followed operational stages ${ }^{(12)}$; the first step consisted in defining the theme and elaborating the guiding question: how is the scientific production addressing the quality of life of people living with HIV and AIDS characterized, as published in dissertations and theses in Brazil? 
In the second stage, empirical material was collected. To do so, in June 2018, dissertations and doctoral theses were surveyed in the Brazilian Digital Library of Theses and Dissertations, linked to the Brazilian Institute of Information in Science and Technology. The terminology in health based on the Health Sciences Descriptors (DeCS) was used in this step.

It should be noted that, in order to observe the state of the art from sensu stricto Brazilian graduate programs on the subject studied, it was decided to investigate the theses and dissertations instead of original articles because the dissemination of the articles coming from the gray literature hardly takes place in a timely manner after the defense of these works ${ }^{(13)}$.

For the search of studies, the descriptors 'HIV', 'AIDS' and 'quality of life' were used, combined with the Boolean operator AND, with the condition of presence of the word in the title of the study, in order to refine the search with a focus on the target thematic area, resulting in the identification of 105 studies (dissertations and theses).

The inclusion criteria to select the sample were: studies published from 2005 to 2018 , because this is considered a period in which scientific and technological advances related to the treatment of HIV and AIDS were disseminated by the scientific community; studies discussing the quality of life of people living with HIV and AIDS; and studies available online in the Brazilian Digital Library of Theses and Dissertations. As exclusion criterion: studies that did not use general or specific instruments to evaluate quality of life.

After a thorough reading of the abstracts of the works and in compliance with the established criteria, 31 dissertations and 36 theses were excluded from the present review. Therefore, the sample consisted of 38 studies, among 20 dissertations and 18 theses, which were organized and grouped into a file folder in the Windows 10 operating system.

It should be noted that the sample was selected by two authors, as recommended by the Preferred Reporting Items for Systematic Reviews and Meta-Analysis (PRISMA) statement, allowing inclusion and exclusion criteria to be rigorously followed ${ }^{(14)}$.

In the third stage, from June to July 2018, data were collected using an instrument prepared by the researchers addressing information about the studies, such as year of publication, place of origin of the study according to the geographic region of Brazil and higher education institution of publication, area of academic training of the author, study design, instruments used to measure quality of life, and dimensions of quality of life assessed in the studies on the topic HIV/AIDS.

Then, the fourth stage was started, consisting of the processing of the data in the R-Project software, version 3.5.1. This is a free software environment for statistical and graphical computation. The analyses included descriptive (frequency, mean and median of publications) and inferential statistical analyses, using the non-parametric Mann-Whitney test, which allows verifying whether there are differences in the variables related to the production of dissertations and theses.

The data were presented in texts and graphs, analyzed in light of the literature pertinent to the subject investigated, contemplating the fifth and final operational stage of this study.

As this was a bibliometric review study, there was no need for appreciation by an Ethics Committee in Research involving human beings, and the ethical principles from current resolutions and the Code of Ethics of Nursing Professionals were rigorously considered.

\section{Results}

Regarding the characterization of the analyzed studies, it was observed that there was a greater percentage of publications in the year of 2009 (20.0\%), followed by the years of 2011 and 2013 (15.0\% in each year), 2008, 2010 and 2012 (10.0\% in each year), 2005, 2006, 2007 and 2016 (5.0\% in each year). There were no publications in the years 2014, 2015, 2017 and 2018. 
In relation to the publication of theses, the highest number of publications occurred in 2011 (22.2\%), followed by 2010 (16.6\%), 2007, 2009, 2012 and 2013 (11.1\% each year), 2006, 2008 and 2016 (5.6\% in each year). In 2005, 2017 and 2018, no publications of theses were identified.

\section{Annual production of dissertations}

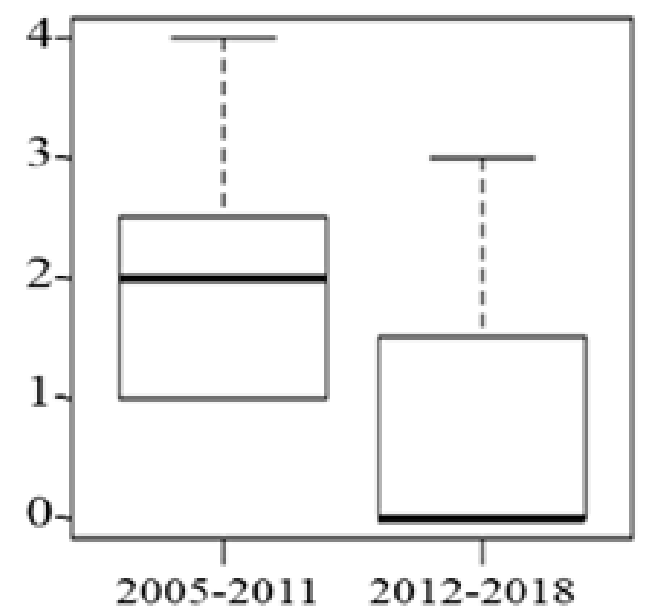

With regard to the year of publication of the studies, the annual production of dissertations and theses was compared between the first seven and the last seven years of the research, as shown in the boxplot presented in Figure 1.

\section{Annual production of theses}

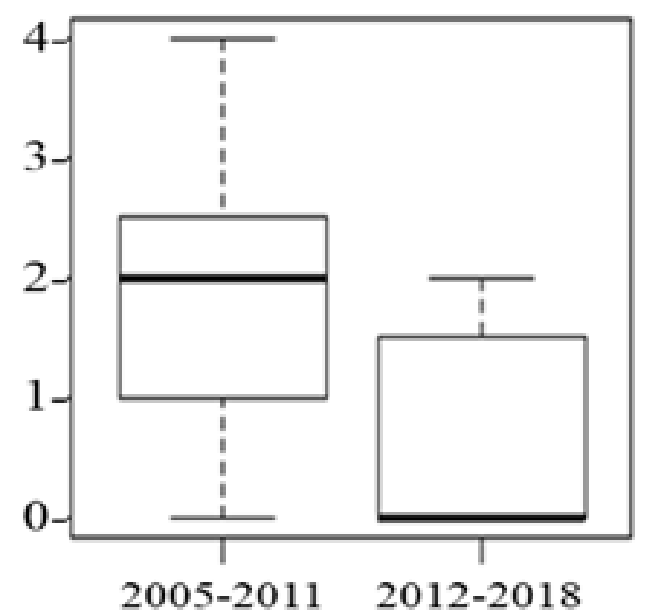

Figure 1 - Median of the annual academic production of dissertations and theses $(n=38)$

With regard to the origin of the studies that composed the sample of this research, scientific productions related to the quality of life of people living with HIV/AIDS were identified in the following higher education institutions located in the four macroregions of the country: University of São Paulo (29,.0\%), Federal University of Paraiba (16\%), Catholic Pontifical University of Rio Grande do Sul (11\%), Federal University of Paraíba (16.0\%), University of Brasília, Federal University of Rio Grande do Norte, Federal University of Rio Grande do Sul and Federal University of Ceará (8.0\% each institution); Paulista State University, Federal University of Santa Catarina, State University of Campinas, Júlio de Mesquita Filho São Paulo State University, and Catholic University of Brasília (3.0\% each institution).
Between 2005 and 2018, the highest number of dissertations was in the Northeast Region (40.0\%), followed by the Southeast (30.0\%), South (20.0\%) and Center-West $(10.0 \% \%)$. With respect to the theses, a greater number of productions was observed in the Southeast (44.0\%), followed by the Northeast and South $(22.0 \%$, respectively), and Central-West Region (12.0\%). For the purpose of sampling, it is relevant to note that there was no scientific production related to the quality of life of people living with HIV and AIDS from institutions in the Northern Region of Brazil.

The Mann-Whitney non-parametric test was used to observe whether there was equality between the medians of the variables addressed in this review, assuming that the samples were independent, with a significance level of $5 \%$. A p $=0.775$ was found. 
Considering the significance level of $5 \%$, the Mann-Whitney test was applied to identify differences in the medians of production of studies by geographic region, and p-values higher than the level of significance were found, as in the Northeast: $\mathrm{p}=0.479$; Southeast: $p=0.879$; South: $p=0.999$; and Center-West: $\mathrm{p}=0.999$.

Regarding the authorship of the dissertations and theses investigated, it was seen that nurses were the ones that most published, appearing in $39.0 \%$ of the studies, followed by psychologists, in $34.0 \%$; physical educators, in 8.0\%; physical therapists and physicians, in $5.0 \%$ each; and dentists, economists and social workers, in $3.0 \%$ each.

Regarding the methodological aspects described in the dissertations and theses investigated, $58.0 \%$ were descriptive, $26.0 \%$ exploratory, and $16.0 \%$ descriptive-exploratory. Regarding the approach, $66.0 \%$ of the studies were quantitative, $29.0 \%$ used the quantitative and qualitative approach, and $5.0 \%$ of the studies were qualitative.

Regarding the technical procedures, most of the studies were field surveys $(76.0 \%)$ followed by quasi experimental studies (10.0\%), cohort studies (5.0\%), procedures of the research-action type, clinical non-randomized trials, and case studies (3.0\%), respectively.

Regarding the approach to health-related quality of life of people living with HIV/AIDS, regarding the dimensions of quality of life assessed in the studies that composed the sample, the physical dimension was the most cited in most studies (27.3\%); followed by the emotional/psychological dimension (26.6\%); social dimension (22.7\%); cultural dimension (14.1\%); and spiritual/religious dimension (9.4\%).

Regarding the specificity of the instruments for assessment of quality of life contained in the sample, $89.0 \%$ of the studies used general tools for assessment of quality of life of people living with HIV and AIDS, namely: the World Health Organization Quality of Life (WHOQOL-120 HIV or WHOQOL-HIV Bref) or the AIDS-Targeted Quality of Life Instrument (HAT-
-QoL) instrument. In $52.7 \%$ of the investigations, generic instruments for assessment of quality of life were used (WHOQOL-100 or WHOQOL-bref); and in $34.2 \%$, instruments for evaluation of anxiety, depression and self-esteem (Beck Depression Inventory, Anxiety and Depression Scale, Rosemberg Self-esteem Scale, and Hope Scale) were used. The studies also used instruments for collection of additional information on sociodemographic data, laboratory test data, as well as semi-structured interview scripts.

\section{Discussion}

One limitation of this study was the non-application of the bibliometrics laws in view of the reduced number of items in the sample, which hindered a more accurate analysis of the characteristics of the analyzed studies.

With regard to the publications of dissertations, in the time period from 2005 to 2018, it was observed in Figure 1 that, according to the sample median, there was a greater publication of dissertations in the early years of academic production, whereas in the final years the median was zero, indicating that in some years there was no production of dissertations on the subject.

The analysis of the production of theses during the time interval studied showed that a greater number of works was published in the initial years. In the final years, there was no production, being the maximum value of publication of theses in the entire period equal to two. The Mann-Whitney test was applied to the data, assuming that the samples were independent, and revealed that the medians of the variables were equal at a significance level of 5\%.

In order to investigate differences in the medians of production of studies according to geographical region, values above the level of significance were observed. This indicates that there was no difference in the medians and the production of dissertations and theses by geographic region can be considered equal. 
Bibliometric analyses are an important methodological resource for health sciences as they reveal patterns of research and identify trends ${ }^{(15)}$. According to the results of this bibliometric study, an advancement of the research on the theme in Brazil was observed from 2006 to 2012, with a clear significant decrease in recent years. Despite the decrease of studies published at the sensu stricto level between 2014 and 2015 , a concern of researchers with the evaluation of the quality of life of people living with HIV and AIDS was observed.

Regarding the place of origin of the studies, there was a predominance of institutions from the Northeast and Southeast Regions of Brazil. This result may be justified by the need for development of research and strategies to support decision making in these regions, given the greater occurrence of notifications of HIV infection there ${ }^{(16)}$. The result also corroborates a review study that explains the high number of productions on the quality of life of people living with HIV and AIDS in the Brazilian Southeastern Region based on the concentration of graduate programs in the health area, besides health services and a high number of cases of infection in this region ${ }^{(17)}$.

It was observed in this bibliometric review that professionals from various areas of knowledge have shown interest in the theme in focus. However, a descriptive study carried out in Bahia, Brazil, involving professionals from health and social sciences who worked directly with people living with HIV/AIDS demonstrated that despite the advances related to the approach and management in the treatment of this disease, the prejudice among these professionals still persists and can negatively influence their practice of care provision. Thus, it is necessary to strengthen interdisciplinary actions in order to promote comprehensive care, free from any stereotype, with a view to promoting the quality of life of people living with HIV/AIDS ${ }^{(18)}$.

In view of the above, although antiretroviral treatment is a positive aspect, when allied with the chronicity of AIDS may interfere in the physical and mental health and the well-being of people who use it, leading to negative situations in the quality of life of individuals. Coping with this problem can bring with it circumstances of exclusion and stigma on the part of society, causing a rupture in interpersonal relationships of affection, sexuality and socialization ${ }^{(19-20)}$.

This corroborates studies analyzed in this review, which identified in their evaluation of quality of life that the physical dimension was the most present. This shows that the manifestations imposed by the disease related to HIV infection and AIDS can interfere with people's quality of life, affecting activities of daily living and making individuals feel less socially impor$\operatorname{tant}^{(21)}$.

The emotional/psychological dimension may be affected by the fact that the individual has a chronic and incurable condition, as well as by the stigma that still exists due to the lack of knowledge about the disease and the treatment. In the social dimension, the detachment from friends and family stands out, hindering family interactions, making individuals to isolate in society and have low self-esteem ${ }^{(4)}$. The feeling of guilt can also occur when a condition is considered a social deviation from the heteronormative idea that still prevails in the current collective imagination ${ }^{(18)}$.

The present study showed that Nursing and Psychology are responsible for most of the publications on the topic of Quality of Life related to the Health of people living with HIV and AIDS. This may be associated with the fact that the diagnosis of HIV infection has biopsychosocial implications, since it is a chronic infection with an emotional impact on its effective control, rasing new challenges for patients and health professionals ${ }^{(22)}$.

Due to the fact that the nursing category deals with people in hospital institutions in a daily basis and also because in the discussion of how to train professionals capable of understanding the complexity of aids, based on the psychosocial dimensions, there is a clear importance and need for research in this theme, 
in the attempt to improve nursing care in the area of care for people living with HIV and $\operatorname{AIDS}^{(23)}$. This confirms the findings of the present study, in which nursing has been leading the Brazilian scientific production on the quality of life of infected people.

In this discussion, in view of the complexity of the health care for people living with HIV and AIDS, interdisciplinary and intersectoral work is imperative in the search for strengthening a network of care for HIV/AIDS, with an integrated approach and comprehensive assistance to people living with HIV/AIDS. This can be achieved through a joint intervention plan involving professionals, health service teams and managers and sectors of society in the attempt to respond positively to the needs presented by users ${ }^{(24)}$.

It is pointed out that the studies developed on the theme at the national level are characteristic of the health knowledge field. It is, therefore, urgent that Nursing and Psychology professionals seek evidence about facts or circumstances that affect the quality of life of these people in order to demonstrate the concern of the categories in developing more humanized care, focused on biopsychosocial issues of people living with HIV/AIDS.

Health care consists in the practice of caring for individuals in a comprehensive way, embracing them by listening to them and with a sensitive perspective during therapy, making it possible to care for individuals in their subjectivity, culture and history, not only focusing on the disease, but also on the persons live with the problem ${ }^{(21)}$. A study on the quality of life of women living with HIV demonstrated the need for well-structured social support to enable positive quality of life in people living with HIV and $\operatorname{AIDS}^{(25)}$.

In the content of this trend, the studies should address the quality of life to be measured with technical and scientific rigor, focusing on the cultural, social, political and economic dimensions of the human being. This can have an impact on the care of patients, solidifying the clinical practice of health professionals based on the scientific literature produced. By addres- sing the concept of quality of life in a well defined way, researchers could delineate studies with the greatest possible accuracy, conferring reliability to the theory and later application in the praxis of health professionals and related areas.

It is, therefore, important to highlight the different ways of measuring the quality of life, considering the subjectivity of the evaluation. Instruments that have scientific and technical rigor must be used. Scales for measuring the dimensions of quality of life should follow scientific precision and well defined statistical parameters in order to allow a reliable result to the study findings. Therefore, instruments in scientific research must be related to the purpose of what is expected from the findings, where a specific purpose is essential, with validation of the applicability to the object of the study ${ }^{(26)}$.

In the present survey, the analyzed studies evaluated the quality of life of people living with HIV and AIDS using general and specific instruments validated in Brazil. Some of these studies also used instruments of evaluation of depression, anxiety and self-esteem.

In particular, it is noteworthy that it is important to use valid and reliable instruments for what the study proposes to measure, so as to effectively reveal the knowledge about the living conditions of people who suffer with the chronic infection, according to the requirements of the disease and its physical, psychological, social, and spiritual repercussions. The later can lead to significant social changes, compromising interpersonal relationships and causing low self-esteem and lifestyle changes, with a negative impact on the quality of life of these people ${ }^{(27)}$.

It is necessary, therefore, to apply instruments in the methodological course of the research that evaluate the dimensions of the human being with a view to reverse situations of negativity that interfere with the daily lives of people living with HIV infection.

The results found in this study also showed an incipient production focused on the spirituality/religiosity of people living with HIV and AIDS. Religiosity 
is important in the treatment of the infection because it may contribute to the process of adherence to drug therapy. Thus, it seems necessary that professionals develop care practices related to spirituality in order to improve the health care for people living with HIV and AIDS and, consequently, the quality of life of patients $^{(28)}$.

In the practice, the psycho-spiritual dimension (although referred to as support for the treatment of people living with HIV and AIDS) is still little incorporated into professional practices in specialized care services. Therefore, more studies exploring the contexts in which spirituality is involved in the treatment of HIV infection are necessary ${ }^{(29)}$.

The relevance of the implementation of spirituality as an adjunct to drug therapy is therefore clear, for it allows the provision of comprehensive health care and meeting the needs in all the dimensions of the people living with HIV and AIDS, which can consubstantially improve their quality of life.

\section{Conclusion}

In recent years, there has been a significant production in Brazilian graduate studies on the quality of life of people living with HIV and AIDS. The Southeast and Northeast regions lead the scientific production at the sensu stricto level, with the Federal University of São Paulo and the Federal University of Paraíba being the institutions that published more works. The tendency to believe that this theme belongs only to the health area was confirmed.

The set of findings of this study brings evidence regarding the evaluation of the physical, social, emotional and psychological dimensions of the quality of life of people living with HIV and AIDS, as opposed to the cultural and spiritual/religious dimension, which is therefore a gap of knowledge in most of the studies analyzed.

\section{Collaborations}

Silva Júnior SV, Silva WJC, Lourenço NS, Nogueira JA, Oliveira e Silva AC and Freire MEM participated in the planning and designing or analysis and interpretation of data, writing of the article, critically review of the intellectual content, and final approval of the version to be published.

\section{References}

1. Ministério da Saúde (BR). Secretaria de Vigilância em Saúde. Boletim Epidemiológico HIV/Aids [Internet]. 2017 [citado 2019 jan. 23]; 48(1):152. Disponível em: http://portalarquivos2.saude. gov.br/images/pdf/2017/janeiro/05/2016_034Aids_publicacao.pdf

2. Okuno MFP, Gomes AC, Meazzini L, Scherrer Júnior G, Belasco Junior D, Belasco AGS. Qualidade de vida de pacientes idosos vivendo com HIV/ Aids. Cad Saúde Pública. 2014; 30(7):1551-9. doi: http://dx.doi.org/10.1590/0102-311X00095613

3. Ministério da Saúde (BR). Secretaria de Vigilância em Saúde. Manual técnico para o diagnóstico da infecção pelo HIV em adultos e crianças [Internet]. 2018 [citado 2019 jan. 23]. Disponível em: http:// www.aids.gov.br/pt-br/node/57787

4. Domingues JP, Oliveira DC, Marques SC. Quality of life social representations of people living with HIV/Aids. Texto Contexto Enferm. 2018; 27(2):e1460017. doi: dx.doi.org/10.1590/0104070720180001460017

5. Freire MEM, Sawada NO, França ISX, Costa SFG, Oliveira CDB. Health-related quality of life among patients with advanced cancer: an integrative review. Rev Esc Enferm USP. 2014; 48(2):357-67. doi: 10.1590/S0080-6234201400002000022

6. Soares ASF, Amorim MISPL. Qualidade de vida e espiritualidade em pessoas idosas institucionalizadas. Rev Port Enferm Saúde Mental [Internet]. 2015 [citado 2019 jan. 23]; 2(spe2):45-51. Disponível em: http://www.scielo.mec.pt/pdf/ rpesm/nspe2/nspe2a08.pdf 
7. Alemayehu M, Wubshet $\mathrm{M}$, Mesfin N, Tamiru A, Gebayehu A. Health-related quality of life of HIV infected adults with and without Visceral Leishmaniasis in Northwest Ethiopia. Health Qual Life Outcomes. 2017; 15(65):65. doi: dx.doi. org/10.1186/s12955-017-0636-6

8. Costa JM, Nogueira LT. Fatores associados à qualidade de vida relacionada à saúde de receptores de transplantes renais em Teresina, Piauí, 2010. Epidemiol Serv Saúde. 2014; 23(1):121-9. doi: dx.doi. org/10.5123/S1679-49742014000100012

9. Medeiros B, Silva J, Saldanha AAW. Determinantes biopsicossociais que predizem qualidade de vida em pessoas que vivem com HIV/Aids. Estud Psicol (Natal). 2013; 18(4):543-50. doi: http://dx.doi. org/10.1590/S1413-294X2013000400001

10. Agra MAC, Freitas TCS, Caetano JÁ, Alexandre ACS, Sá GGM, Galindo Neto NM. Nursing dissertations and theses on the mobile emergency care services: a bibliometric study. Texto Contexto Enferm. 2018; 27(1):e3500016. doi: dx.doi.org/10.1590/010407072018003500016

11. Portal SG. Una nueva perspectiva teórica de la bibliometría basada en su dimensión histórica y sus referentes temporales. Investig Bibl. 2016; 30(70):11-6. doi: dx.doi.org/10.1016/j.ibbai.2016.10.001

12. Vanz SAS, Stumpf IRC. Colaboração científica: revisão teórico-conceitual. Perspect Ciênc Inf. 2010; 15(2):42-55. doi: http://dx.doi.org/10.1590/ S1413-99362010000200004

13. Costa ICP, Costa SFG, Andrade CG, Oliveira RC, Abrão FMS, Silva CRL. Scientific production on workplace bullying/harassment in dissertations and theses in the Brazilian scenario Rev Esc Enferm USP. 2015; 49(2):265-74. doi: dx.doi. org/10.1590/S0080-623420150000200012

14. Moher D, Liberati A, Tetzlaff J, Altman DG, PRISMA Group. Preferred reporting items for systematic reviews and meta-analyses: the PRISMA statement. Ann Intern Med. 2009; 151(4):264-9. doi: http://dx.doi.org/10.7326/0003-4819-1514-200908180-00135
15. Luna IT, Silva KL, Oliveira SKP, Lima FET, Araújo TL, Damasceno MMC. Analysis of references of the brazilian nursing doctoral thesis: bibliometric study. Rev Enferm UFPE on line [Internet]. 2015 [cited Jan. 13, 2019]; 9(5):7753-9. Available from: periodicos.ufpe.br/revistas/revistaenfermagem/ article/view/10521/0

16. Ministério da Saúde (BR). Secretaria de Vigilância em Saúde. Boletim Epidemiológico HIV/Aids [Internet]. 2016 [citado 2019 jan. 23]. Disponível em: http://www.aids.gov.br/pt-br/pub/2016/ boletim-epidemiologico-de-aids-2016

17. Silva FS, Oliveira FBM, Mendes ACC, Silva G, Santos SO, Pessoa RMC. Preditores associados à qualidade de vida em pessoas vivendo com HIV/ Aids: revisão integrativa. Rev Prev Infecç Saude [Internet]. 2015 [citado 2019 jan. 23]; 1(2):5363. Disponível em: http://www.ojs.ufpi.br/index. php/nupcis/article/view/3589/pdf

18. Suto CSS, Oliveira JF, Paiva MS. Social Representations of health care professionals on Acquired Immune Deficiency Syndrome. Rev Bras Enferm. 2018; 71(4):1934-9. doi: http://dx.doi. org/10.1590/0034-7167-2015-0001

19. Villela WV, Monteiro S. Gênero, estigma e saúde: reflexões a partir da prostituição, do aborto e do HIV/Aids entre mulheres. Epidemiol Serv Saude. 2015; 24(3):531-40. doi: http://dx.doi. org/10.5123/S1679-49742015000300019

20. Araújo MAD, Carvalho DMS, Oliveira HJP, Nascimento LG, Santos ACC. A abordagem atual a mulher soropositiva para o HIV frente a maternidade: revisão integrativa. Rev Saúde [Internet]. 2017 [citado 2019 jan. 23]; 11(1): 41. Disponível em: http://revistas.ung.br/index.php/saude/article/ view/3141/2264

21. Calvetti PÜ, Giovelli GRM, Gauer GJC, Moraes JFD. Níveis de ansiedade, estresse percebido e suporte social em pessoas que vivem com HIV/Aids. Psicol Teor Pesq. 2016; 32(4):e324317. doi: http:// dx.doi.org/10.1590/0102.3772e324317

22. Camillo SO, Maiorino FT, Chaves LC. Nursing teaching on HIV/Aids in the perspective of citizenship. Rev Gauch Enferm. 2013; 34(3): 117-23. doi: http://dx.doi.org/10.1590/S198314472013000300015 
23. Lopes LM, Magnabosco GT, Andrade RLP, Ponce MAZ, Wysocki AD, Ravanholi GM, etal. Coordenação da assistência prestada às pessoas que vivem com HIV/Aids em um município do Estado de São Paulo, Brasil. Cad Saúde Pública. 2014; 30(11): 2283-97. doi: dx.doi.org/10.1590/0102-311X00091213.

24. Fernandes ES, Almeida IS, Costa CCP, Ribeiro IB. A vivência do ser-adolescente com HIV/Aids: um estudo fenomenológico para a enfermagem. Rev Enferm Prof [Internet]. 2014 [citado 2019 mar. 22]; 1(2):447-61. Disponível em: https://docplayer. com.br/36947218-Rev-enf-profissional-jul-dez1-2-447-issn.html

25. Bellini JM, Reis RK, Reinato LAF, Magalhães RLB, Gir E. Quality of life of HIV seropositive women. Acta Paul Enferm. 2015; 28(4):350-4. doi: http:// dx.doi.org/10.1590/1982-0194201500059

26. Machado CJ, Pereira CA. Instrumentos de coleta de dados na saúde pública: resenha crítica da obra de Monteiro e Horta. Cad Saúde Coletiva. 2014; 22(4):437-8. doi: http://dx.doi. org/10.1590/1414-462X201400040002
27. Hipolito RL, Oliveira DC, Costa TL, Marques SC, Pereira ER, Gomes AMT. Quality of life of people living with HIV/Aids: temporal, sociodemographic and perceived health relationship. Rev Latino-am Enfermagem. 2017; 25:e2874. doi: https://doi.org/10.1590/1518-8345.1258.2874

28. Oliveira ADF, Vieira MCA, Silva SPC, Mistura C, Jacobi CS, Lira MOSC. Effects of HIV in daily life of women living with AIDS. Rev Pesqui Cuid Fundam On line. 2015; 7(1):1975-86. doi: 10.9789/21755361.2015.v7i1.1975-1986

29. Espírito Santo CC, Gomes AMT, Oliveira DC, Marques SC. Antiretroviral treatment adherence and the spirituality of people with HIV/Aids: social representations study. Rev Enferm UERJ [Internet]. 2013 [cited Jan. 21, 2019]; 21(4):45863. Available from: https://www.e-publicacoes. uerj.br/index.php/enfermagemuerj/article/ view/10005/8130 